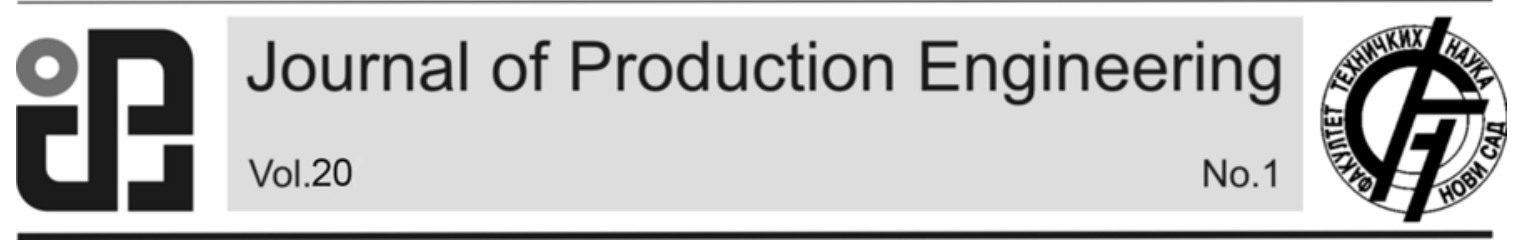

JPE (2017) Vol.20 (1)

Agboola, O. O., Ikubanni, P. P.

Preliminary Note

\title{
APPLICATION OF STATISTICAL QUALITY CONTROL (SQC) IN THE CALIBRATION OF OIL STORAGE TANKS
}

Received: 22 April 2017 / Accepted: 05 May 2017

\begin{abstract}
Calibration of storage tanks is an exact means of determining the accurate capacity of storage tanks at a given incremental level. When calibrating a certain number of oil storage tanks having the same dimensions, it is assumed that if the specified tank dimensions are within the statistical control limits, a calibration chart generated for one tank can be used for the other tanks. This study used X-bar and R-control chart to investigate the stability of the tank calibration process for some fabricated oil storage tanks. The method of control chart was used to check if the process is under control or not. The variables of the calibration process are Circumference of each course shell, Height of each course shell and Elevations for the bottom profile. Results revealed that the calibration process was statistically stable and under control with no special or assignable cause of variation. Process capability conducted also showed that the calibrated tanks met the pre-set limits.
\end{abstract}

Key words: Calibration, Process capability, Quality Control, Storage tanks, X-bar \& R-Chart

Primena statističke kontrole kvaliteta (SQC) u kalibraciji uljnih rezervoara. Kalibracija rezervoara je egzaktna metoda utvrđivanja tačnog kapacitet rezervoara pri datom inkrementalnom nivou. Kada se kalibriše određeni broj rezervoara nafte koji imaju iste dimenzije, pretpostavlja se da ako su dimenzije navedenog rezervoara u granicama statističkih odstupanja, grafikon kalibracija generisana za jedan rezervoar može se koristiti i za druge rezervoare. Ova studija koristi X-bar i R-kontrolne karte za ispitivanje stabilnosti procesa kalibracije rezervoara za neke gotove rezervoare za skladištenje nafte. Metod kontrolne karte je korišćen da se proveri da li je proces pod kontrolom ili ne. Promenljive procesa kalibracije su obim svakog predmeta ljuske, visina svakog kursa ljuske i profil uzvišenja danca. Rezultati ukazuju da je proces kalibracije bio statistički stabiln i pod kontrolom bez posebnih uzroka varijacija. Sprovedeni proces je takođe pokazao da su kalibrisani rezervoari bili u unapred utvrđeneim granicama.

Ključne reči: kalibracija, proces sposobnosti, kontrole kvaliteta, rezervoari, $X$-bar \& $R$ - karte

\section{INTRODUCTION}

Calibration of storage tanks is an exact means of determining the accurate capacity of storage tanks at a given incremental level [1]. It is essential to accurately determine the quantity of product going in and coming out of the storage tanks for proper inventory control. Crude oil and its refined products are precious fluids owing to their market value and therefore cannot be sold above the expected measured quantity to the customers and also cannot be bought below the expected quantity from the suppliers. Various geometrical methods of tank calibration such as Manual Strapping Method (MSM), Optical Reference Line Method (ORLM), Optical Triangulation Method (OTM), and Electro-Optical Distance Ranging Method (EODRM) had been identified and discussed by [2] and [3].

In Nigeria, the most applicable geometrical method that is prevalently used for storage tank calibration is Manual Strapping Method [3]. The required field data that must be accurately determined while using MSM are Circumference of each Course Shell, Height of Each Course, and Elevations for the Bottom geometry/profile [4] [5]. Experimental research is considered necessary for a group of storage tanks (uniform dimensions) fabricated by the same company but for different clients. This is to see if the aforementioned required field data (Circumference,
Height, Elevations of bottom) are within the statistical control limit in order to check whether the calibration chart generated for one of the tanks in the group can be used for the others. Though X-bar and R-chart and Xbar and S-chart are variable charts for sub-group; however, X-bar and R-chart was chosen as the most preferred Statistical Quality Control Chart (SQCC) for this study because data sub-group was less than eight (8) and also because only few works had been done using it. Tank calibration process involves adequate planning and scheduling as proper scheduling saves time and minimizes cost [6]. Hence, each of the above identified variable data are properly scheduled to obtain optimal output. The quality control analysis of any product is determined by its conformity with the standard set dimensions [7]. Statistical quality control uses different dimensions to evaluate the quality of products. The said dimensions could be conformance to the set limits, maintainability, serveability, availability and durability [8]. [9] improved on the works of [10] and [11] by going beyond the design and application of Cumulative Sum (Cum-Sum) control chart but stated when to use it with much emphasis on practical problems as regards to monitoring changes in the parameters. [12] applied X-bar and $S$ charts to investigate process stability in Electric Wire Industry and was able to show that that the production process was in statistical process control with respect to the diameter and electrical resistance of the without any 
assignable cause of variation.

[13] used statistical calculations to eliminate quality problems such as undesirable tolerance limits and out of circularity of spheroidal cast iron parts during machining. X-bar and $\mathrm{R}$ control charts was constructed based on the data obtained from this manufacturing to detect and eliminate assignable causes, so that the machine capability $(\mathrm{Cp})$ and the process capability (Cpk) can be ascertained. In order to compare design tolerance on working drawings and attained tolerances on work pieces after machining five mass production lines were set up in a medium sized company. The results obtained from five $\mathrm{X}-\mathrm{R}$ control charts and the data gathered from all production lines were processed and evaluated. At this stage of the study, it was observed that some parts were oval and out of tolerance limits, machines and processes were insufficient and production was unstable. Through follow up studies on machine data, some assignable causes for faulty work pieces were discovered, and ovalness and out of tolerance limits errors were corrected. Their findings showed that in small or medium sized companies, statistical quality control can be useful component of production provided that sufficient finance and qualified personal are used.

Pattern recognition techniques have been widely applied to identify unnatural patterns in control charts [14]. [14] presented a control chart pattern recognition system using a statistical correlation coefficient method. Most of them are capable of recognizing a single unnatural pattern for different abnormal types. However, before an unnatural pattern occurs, a change point from normal to abnormal may appear at any point in control charts for most practical cases. Moreover, concurrent patterns where two unnatural patterns simultaneously exist may also occur in a control chart pattern recognition system. They concluded by confirming that statistical correlation coefficient approach is a simple mechanism for recognizing these unnatural control chart patterns with good performance. Cumulative Sum (CUSUM) chart, one of the Statistical Process Control (SPC) techniques, is a powerful tool in monitoring emissions data so that abnormal changes can be detected in a timely manner, using process capability indices to evaluate environmental performance in terms of the risk of non-compliance situations arising [15]. It explores how process capability indices have the potential to be useful as a risk management tool for practitioners and to help regulators execute and prioritize their enforcement efforts. [16] used X-bar and $\mathrm{R}$ Control chart in manufacturing industry to enhance productivity while minimizing defective products, thereby solving rejection problem. They used Apurvi Industries in India as a case study, out of control process was detected by $\mathrm{X}$-bar and $\mathrm{R}$ chart and the root cause analysis was performed on the defective KSB Pumps.

One of the Calibration Companies in Nigeria, Concise Engineering \& Technical Services Limited who has calibrated more than $90 \%$ of the tank fabricated by DeltaWeld Engineering Limited was consulted to get some of the field data. In 2015, DeltaWeld was awarded a contract of fabricating
15 Nos Oil storage tanks by Alluvial Oil in its new depot. Calibration of the said tanks was subsequently given to Concise Engineering. The method of calibration employed by Concise Engineering was MSM which involves accurate measurement of circumference by winding a strapping tape round each course shell. Pocket tape was used to determine the height of each course while the Leveling instrument was used to obtain the Elevations for the bottom profile. The measured field data for each fabricated tank was collected and checked if they are within the statistical control limit using X-bar and R control chart. Available data revealed that each tank has five (5) course shells with an average capacity of 1,500,000 litres. Hence, the work aimed at using the X-bar and Rchart in determining the stability and capability of calibration process for same set of oil tanks.

\section{MATERIAL AND METHOD}

Related data needed for the calibration were obtained directly from the field engineer. The data include: 1.) Circumference of each course, 2.) Height of Course Shells, and 3.) Elevations of the Bottom profile. Plate thicknesses for each course shell were not considered because they were all new tanks. Each of the above-mentioned data was analyzed using Minitab 17. X-bar charts were first drawn followed by R-charts but the analysis for the stability of tank calibration process started from R-chart using "Run rules". If the $\mathrm{R}$-charts indicate that the calibration process is stable, we then proceed to X-bar charts to further confirm the process stability. If both conditions for stability were met, then the next step was to check if the calibrated tanks were within the predefined specifications/limits. The predefined limits for the Circumference, Height of Course Shell and Elevations of the Bottom profile are $\pm 30 \mathrm{~mm}, \pm 20 \mathrm{~mm}$ and $\pm 10 \mathrm{~mm}$ respectively. It is not only enough to confirm the stability of the calibration process but there is also need to find out if the products (fabricated tanks) were within the specified limit. Process Capability was employed to check if the products are within the preset limits.

Strapping tape (Figure 1) was used for measuring the circumference of each course shell by winding it firmly round the tank shell. Pocket tape (Figure 2) and leveling instrument (Figure 3) were used to measure the Course shell height and elevation for bottom profile respectively.

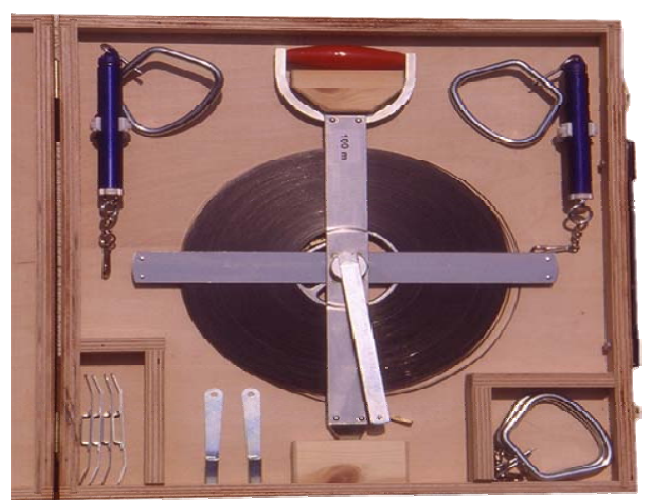

Fig. 1. Strapping tape and its ancillary 


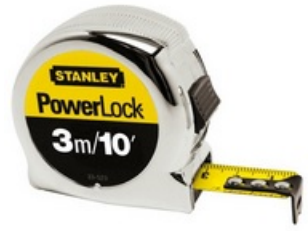

Fig. 2. Pocket tape

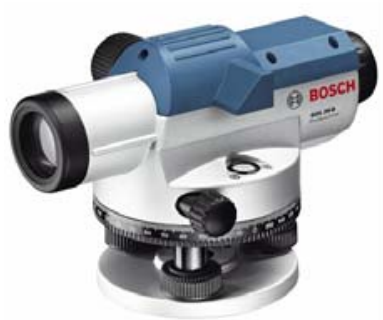

Fig. 3. Leveling instrument

\subsection{X-bar and R-Control Charts}

$\mathrm{X}$-bar and R-Control Charts is one of the Statistical Process Control (SPC) methods used for monitoring and improving a company's quality and productivity. $\mathrm{X}$-bar chart is used to monitor the average value of a process over time. For each subgroup, the x-bar value is plotted. The upper and lower control limits define the range of inherent variation in the subgroup means when the process is in control.

R-Chart on the other hand is a control chart that is used to monitor process variation when the variable of interest is a quantitative measure. These charts give deviations from desired limits within the quality process and, in effect, allow the company to make necessary adjustments to improve quality.

The following are the steps for constructing X-bar and R-charts.

i. Collection and entering of the data into sub-group ii. Determination of the Average $\bar{X}$ of each subgroup;

$$
\bar{X}=\frac{X_{1}+X_{2}+X_{3} \ldots \ldots X_{n}}{n}
$$

iii. Calculate the grand mean $\overline{\bar{X}}$ of the sub-group's average. The grand mean of the subgroup's average becomes the centerline for the upper plot.

$$
\overline{\bar{X}}=\frac{\bar{X}_{1}+\bar{X}_{2}+\bar{X}_{3} \ldots \ldots \bar{X}_{n}}{n}
$$

iv. Determine the Range $\mathrm{R}$ of each sub-group by subtracting lowest value from the highest value in the sub-group. Range $=$ Highest-Lowest

v. Calculate average of subgroup Ranges

$$
\bar{R}=\frac{R_{1}+R_{2}+R_{3} \ldots \ldots R_{n}}{k}
$$

vi. Determine the Upper Control Limit UCL and Lower Control Limit LCL for sub-group averages.

For X-bar chart:

$$
\begin{aligned}
& U C L_{\bar{X}}=\overline{\bar{X}}+A_{2} \bar{R} \\
& L C L_{\bar{X}}=\overline{\bar{X}}-A_{2} \bar{R}
\end{aligned}
$$

For R-chart:

$$
\begin{aligned}
& U C L_{\bar{R}}=D_{4} \bar{R} \\
& L C L_{\bar{R}}=D_{3} \bar{R}
\end{aligned}
$$

\section{RESULTS AND DISCUSSION}

\subsection{Results}

The measured field data as entered into sub-group, the mean as well as the range for the Circumference of Course shells, Height of Course shells and Elevations for Bottom Profile were presented in Table 1, Table 2 and Table 3 respectively.

\begin{tabular}{cccccccc}
\hline Tank & $\mathrm{C}_{1}$ & $\mathrm{C}_{2}$ & $\mathrm{C}_{3}$ & $\mathrm{C}_{4}$ & $\mathrm{C}_{5}$ & Average & Range \\
\hline 1 & 56050 & 56046 & 56061 & 56063 & 56055 & 56055 & 17 \\
2 & 56055 & 56062 & 56071 & 56063 & 56064 & 56063 & 16 \\
3 & 56061 & 56058 & 56056 & 56056 & 56051 & 56056.4 & 10 \\
4 & 56065 & 56063 & 56064 & 56066 & 56058 & 56063.2 & 8 \\
5 & 56058 & 56062 & 56062 & 56065 & 56050 & 56059.4 & 15 \\
6 & 56063 & 56064 & 56064 & 56061 & 56053 & 56061 & 11 \\
7 & 56061 & 56058 & 56056 & 56050 & 56046 & 56054.2 & 15 \\
8 & 56065 & 56063 & 56064 & 56070 & 56058 & 56064 & 12 \\
9 & 56061 & 56063 & 56055 & 56072 & 56063 & 56062.8 & 17 \\
10 & 56069 & 56063 & 56064 & 56056 & 56056 & 56061.6 & 13 \\
11 & 56064 & 56072 & 56063 & 56062 & 56062 & 56064.6 & 10 \\
12 & 56061 & 56071 & 56056 & 56066 & 56065 & 56063.8 & 15 \\
13 & 56063 & 56058 & 56063 & 56064 & 56050 & 56059.6 & 14 \\
14 & 56060 & 56061 & 56061 & 56053 & 56050 & 56057 & 11 \\
15 & 56053 & 56050 & 56058 & 56062 & 56062 & 56057 & 12 \\
\hline
\end{tabular}

Table 1. Samples Circumference of Course Shells

Using equation 3 through equation 8 , the following information were obtained from Table 1 which were used to construct X-bar and R-chart in Figure 4. 
Grand mean $\overline{\bar{X}}=56060.17$, Average Range $U C L_{\bar{R}}=27.63, L C L_{\bar{R}}=0$

$\bar{R}=13.07, \quad U C L_{\bar{X}}=56067.71, L C L_{\bar{X}}=56052.64$,

\begin{tabular}{cccccccc}
\hline Tank & $\mathrm{H}_{1}$ & $\mathrm{H}_{2}$ & $\mathrm{H}_{3}$ & $\mathrm{H}_{4}$ & $\mathrm{H}_{5}$ & Average & Range \\
\hline 1 & 1200 & 1211 & 1209 & 1207 & 1207 & 1206.8 & 11 \\
2 & 1202 & 1200 & 1208 & 1215 & 1212 & 1207.4 & 15 \\
3 & 1195 & 1199 & 1203 & 1205 & 1204 & 1201.2 & 10 \\
4 & 1207 & 1201 & 1198 & 1199 & 1201 & 1201.2 & 9 \\
5 & 1210 & 1205 & 1206 & 1208 & 1202 & 1206.2 & 8 \\
6 & 1206 & 1200 & 1201 & 1198 & 1195 & 1200 & 11 \\
7 & 1205 & 1200 & 1195 & 1192 & 1207 & 1199.8 & 15 \\
8 & 1204 & 1201 & 1193 & 1198 & 1205 & 1200.2 & 12 \\
9 & 1205 & 1200 & 1203 & 1199 & 1196 & 1200.6 & 9 \\
10 & 1197 & 1201 & 1206 & 1210 & 1209 & 1204.6 & 13 \\
11 & 1198 & 1199 & 1208 & 1200 & 1201 & 1201.2 & 10 \\
12 & 1203 & 1201 & 1193 & 1205 & 1204 & 1201.2 & 12 \\
13 & 1205 & 1206 & 1208 & 1205 & 1200 & 1204.8 & 8 \\
14 & 1207 & 1207 & 1193 & 1199 & 1203 & 1201.8 & 14 \\
15 & 1209 & 1207 & 1193 & 1198 & 1205 & 1202.4 & 16 \\
\hline
\end{tabular}

Table 2. Samples Height of Course Shells

Using equation 3 through equation 8 , the following information were obtained from Table 2 which were used to construct X-bar and R-chart in Figure 5.

Grand mean $\overline{\bar{X}}=1202.63$, Average Range $\bar{R}$ $=11.53, U C L_{\bar{X}}=1209.28, L C L_{\bar{X}}=1195.97$, $U C L_{\bar{R}}=24.39, L C L_{\bar{R}}=0$

Using equation 3 through equation 8 , the following information were obtained from Table 3 which were used to construct X-bar and R-chart in Figure 6.

Grand mean $\overline{\bar{X}}=117.2$, Average Range $\bar{R}$ $=4.067, U C L_{\bar{X}}=119.546, L C L_{\bar{X}}=114.854$, $U C L_{\bar{R}}=8.54, L C L_{\bar{R}}=0$

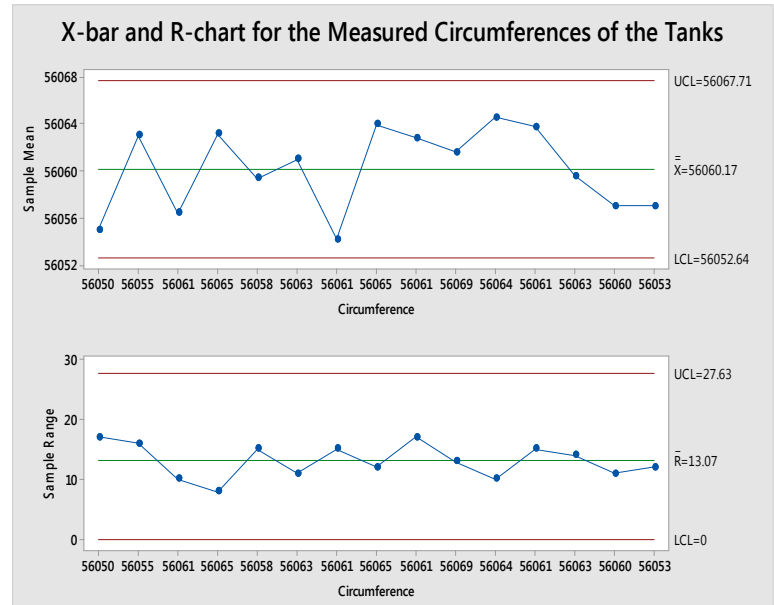

Fig. 4. X-bar and R-chart for the Samples Circumference

\begin{tabular}{cccccccc}
\hline Tank & $\mathrm{E}_{1}$ & $\mathrm{E}_{2}$ & $\mathrm{E}_{3}$ & $\mathrm{E}_{4}$ & $\mathrm{E}_{5}$ & Average & Range \\
\hline 1 & 119 & 118 & 116 & 117 & 115 & 117 & 4 \\
2 & 120 & 119 & 115 & 116 & 117 & 117.4 & 5 \\
3 & 116 & 118 & 119 & 116 & 115 & 116.8 & 4 \\
4 & 120 & 119 & 118 & 116 & 117 & 118 & 4 \\
5 & 116 & 116 & 115 & 117 & 116 & 116 & 2 \\
6 & 118 & 118 & 117 & 115 & 116 & 116.8 & 3 \\
7 & 118 & 117 & 119 & 117 & 116 & 117.4 & 3 \\
8 & 115 & 117 & 118 & 119 & 120 & 117.8 & 5 \\
9 & 119 & 117 & 118 & 116 & 115 & 117 & 4 \\
10 & 118 & 116 & 120 & 119 & 115 & 117.6 & 5 \\
11 & 114 & 117 & 116 & 118 & 115 & 116 & 4 \\
12 & 117 & 119 & 120 & 118 & 116 & 118 & 4 \\
13 & 115 & 117 & 119 & 120 & 118 & 117.8 & 5 \\
14 & 115 & 117 & 116 & 119 & 117 & 116.8 & 4 \\
15 & 115 & 120 & 118 & 116 & 119 & 117.6 & 5 \\
\hline
\end{tabular}

Table 3. Samples Elevation for the Bottom Profile 


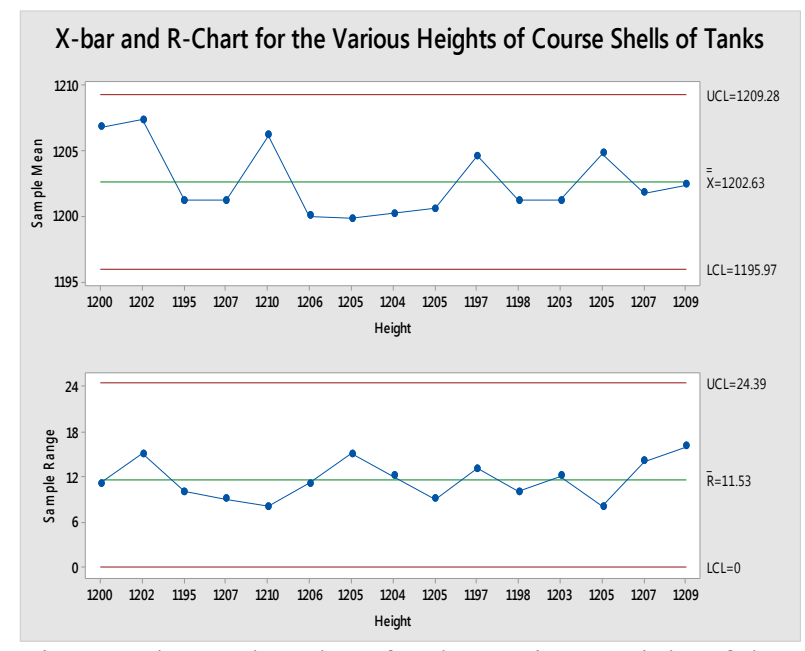

Fig. 5. X-bar and R-chart for the Various Height of the Course Shells

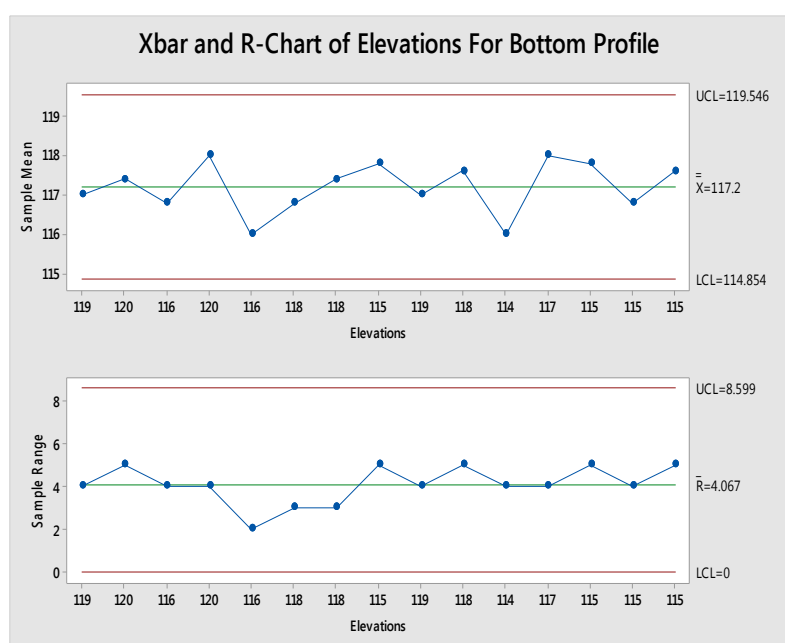

Fig. 6. X-bar and R-chart of Elevations for Bottom Profile

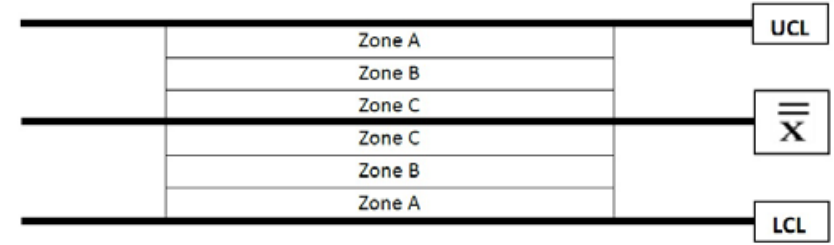

Fig. 7. Analysis of X-bar and R-control chart

\subsection{Discussion}

To check if the calibration process is in control or not, "Run rules" were applied, first to the R-chart and then to the X-Bar chart by dividing the distance between centerline $\mathrm{CL}(\overline{\bar{X}}$ or $\bar{R})$ and Upper Control Limit UCL into three zones $\mathrm{A}(3 \sigma), \mathrm{B}(2 \sigma)$ and $\mathrm{C}(\sigma)$. The same procedure was applied for the distance between the centerline CL and Lower Control Limit LCL as shown in Figure 7.

Analysis of control charts in Figure 4, 5 and 6 revealed the following: 1.) that there is no point outside the LCL and UCL, 2.) that there are no 2 out of 3 subsequent points in Zone $A, 3$.) that there are no 4 out of 5 subsequent points in Zone B or beyond, 4.) that there are no 8 or more points lying on one side of the center line, 5.) that there are no 6 or more subsequent points increasing or decreasing steadily. Control charts in Figure 4, 5 and 6 fulfilled all the conditions set out in Run rules and thereby confirmed that the process is stable (under control) with no assignable cause of variation.

Confirming that a process is stable is not enough; rather, it is expedient to check if calibration variables are within the pre-set limits/specifications. This was the reason for performing Process capability analysis on the obtained field data. The Process capability analysis for the measured Circumference, Height and Elevations were as shown in Figures 8, 9 and 10. Since all the Overall Capability indicators Pp, PPL, PPU, Ppk and $\mathrm{Cpm}$ as well as the Potential Capability (within) indicators $\mathrm{C}_{\mathrm{P}}, \mathrm{C}_{\mathrm{PL}}, \mathrm{C}_{\mathrm{PU}}$ and $\mathrm{C}_{\mathrm{PK}}$ were greater than one, and that implied that the process is capable of giving measurements (products) within the pre-set limits. Also, closer look at the process capability charts (Figures 8 10) revealed that the Normal distribution curves fell between Lower Specified Limit (LSL) and Upper
Specified Limit (USL) which further confirmed the capability of the process.

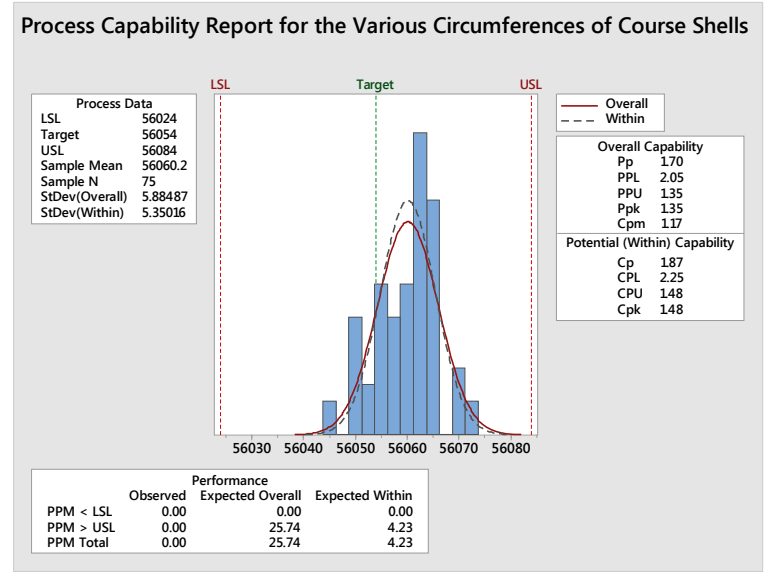

Fig. 8. Process capability analysis for the various Circumferences of Course Shells

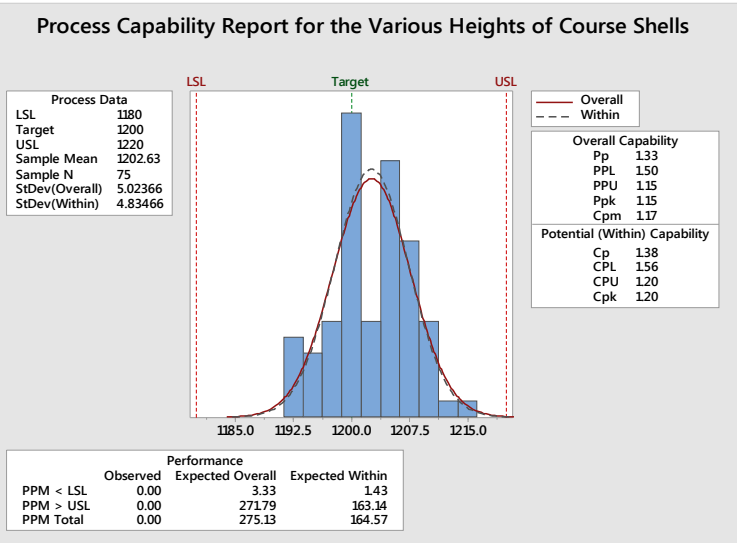

Fig. 9. Process capability analysis for the various Heights of the Course Shells 


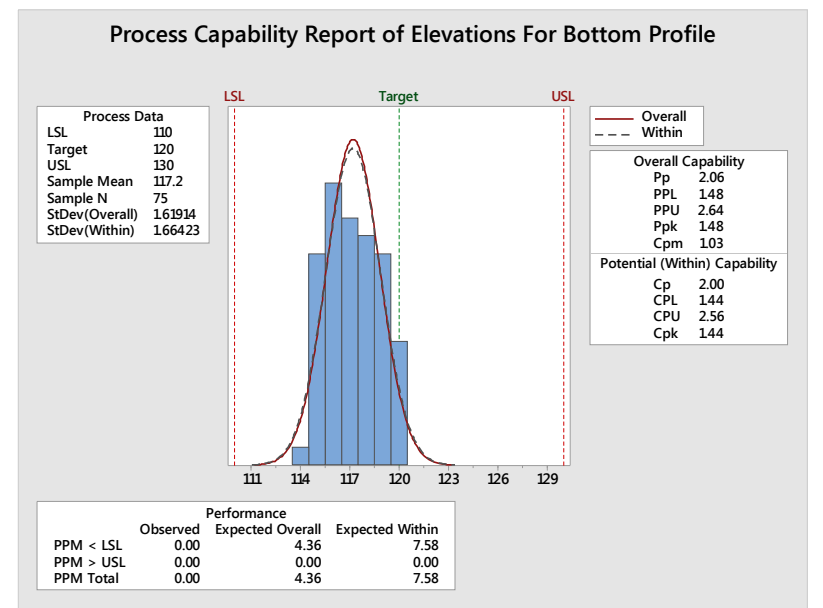

Fig. 10. Process capability analysis for the Elevations for the Bottom Profile

\section{CONCLUSION}

Having successfully applied X-bar and R-control chart to the calibration of storage tanks manufactured by Deltaweld Engineering Limited in Nigeria, it has been observed that there is no assignable (special) cause of variation in the measured field data which could have resulted in sudden sharp change in the calibration chart. Since the calibration process for this group of tanks had been confirmed to be stable with high process capability index. It can be concluded that a calibration chart generated for one tank can be used for other tanks. Using one chart generated for one tank for the other ones will not only save cost but also reduce the time of generating tank calibration chart.

\section{REFERENCES}

[1] ISO 7507: Petroleum and Liquid Petroleum Products-Calibration of Vertical Cylindrical Tanks, ISO copyright office, Geneva, 2002.

[2] Savaraman, S.: Vertical cylindrical storage tank calibration technologies and application, InProceedings of API Conference \& Expo, Singapore, March 2012.

[3] Agboola, O.O., Ikubanni, P. P., Ibikunle, R. A., Adediran, A.A., Ogunsemi B. T.: Generation of Calibration Charts for Horizontal Petroleum Storage Tanks Using Microsoft Excel, MAPANJournal of Metrology Society of India, In press.

[4] Nosach, V., Belyave, B.: The calibration of large vertical cylindrical tank by a geometrical method, Journal of Measurement Techniques, Volume 45, pp 11, 2002.

[5] Makushkin, S. G., Kuzmin, S. A., Kalashnik, G.G.: Tank Deformation and Accuracy in Measuring Oil Product Mass, Chemical and Petroleum Engineering, Volume 37, pp. 278, 2001.

[6] Agboola, O. O., Kareem, B., Akinnuli, B. O.: Development of a diagnostic schedule for a defective LC-195V5 CNC milling machine using PERT, Leonardo Electronic Journal of Practices and Technologies, Volume 28, pp. 107-118, 2016.

[7] Montgomery, D.C.: Introduction to Statistical Quality Control, John Wiley and Sons, Inc., 6th
Edition, USA, 2009.

[8] Steiner, S.H.: Grouped Data Exponentially weighted Moving Average Control Chart, Journal of the Royal Statistical Society, Series C, Volume 47, No. 2, pp. 203-261, 1998.

[9] Ott, E.R., Schilling, E.G., Neubauer, D.V.: Process Quality Control Troubleshooting and Interpretation of Data, ASQ Quality Press, USA, 2005.

[10]Page, E.S.: Cumulative Sum Chart, Technometrics, Volume 3, No. 1, pp. 1-9, 1961.

[11] Woodall, W., Adam, B.: Quality Engineering, Volume 5, No. 4, pp. 559-570, 1993.

[12] Ogedengbe, T. I., Apalowo R. K., Akinde A. B.: Application of Statistical Quality Control for Investigating Process Stability and Control in an Electric Wire Industry, International Journal of Science and Technology, Volume 5, Number 3, pp. 81-87, 2016

[13] Ali, R. M., Abdulkadir, G.: Statistical process control in machining: A case study for machine tool capability and process capability, Materials and Design, Volume 27, pp. 364-372, 2006.

[14] Jenn-Hwai, Y., Miin-Shen Y.: A control chart pattern recognition system using statistical correlation coefficient method, Computers \& Industrial Engineering, Volume 48, pp. 205-221, 2005.

[15]Charles, J. C., Jeh-Nan, P.: Evaluating environmental performance using process control techniques, European Journal of Operational Research, Volume 139, pp. 68-83, 2002.

[16] Kapil, B., Amit P., Diptesh P.: Implementation of Statistical Quality Control (S.Q.C.) in Welded Stainless Steel Pipe Manufacturing Industry, International Journal of Research in Engineering and Technology, Volume 03, Issue 09, pp. 270$273,2014$.

Authors: Engr. Agboola Oluwole Olayinka ${ }^{1}$, Engr. Ikubanni Pelumi Peter ${ }^{1}$

${ }^{1}$ Landmark University Omu Aran, PMB 1001, Omu

Aran, Kwara State, Nigeria.

+2348035411976, +2347065993936

E-mail: agboola.olayinka@lmu.edu.ng ikubanni.peter@lmu.edu.ng 